\title{
PENGARUH MINAT DAN MOTIVASI BELAJAR TERHADAP PRESTASI
} AKADEMIK MAHASISWA SEKOLAH TINGGI BAHASA HARAPAN BERSAMA

\author{
Wiliyanti Then \\ Sekolah Tinggi Bahasa Harapan Bersama \\ Jl. Ayani II Km 7,5, Kubu Raya, Kalimantan Barat, 78391 \\ e-mail : wiliyanti@stbharapanbersama.ac.id
}

\begin{abstract}
Abstrak
Kemampuan bahasa asing dijadikan sebagai suatu persiapan demi meningkatkan kompetensi saat memasuki dunia kerja. Kesadaran itu membuat banyak orang Indonesia tertarik untuk mengikuti kuliah di jurusan bahasa Mandarin. Minat dan motivasi adalah salah satu faktor yang mempengaruhi prestasi belajar. Seseorang dengan minat yang rendah ketika memulai suatu kegiatan akan memiliki rasa malas dan tanpa diimbangi dengan motivasi belajar yang tinggi dapat menyebabkan seseorang kurang tertarik untuk melanjutkan kegiatan tersebut. Oleh karena itu, peneliti ingin mengetahui apakah ada dampak dari minat dan motivasi terhadap prestasi belajar mahasiswa Sekolah Tinggi Harapan Bersama. Metode penelitian yang digunakan pada penelitian ini adalah metode deskriptif dengan teknik pengumpulan data melalui kuesioner dan studi dokumenter dengan anggota populasi adalah Mahasiswa Sekolah Tinggi Bahasa Harapan Bersama. Terdapat tiga variabel yang dikaji dalam penelitian ini, yaitu: minat belajar (X1), motivasi belajar (X2) dan prestasi belajar (Y). Adapun teknik analisis data yang digunakan adalah teknik analisis kualitatif dan kuantitatif menggunakan program SPSS 17.0 dengan regresi linear berganda untuk mengetahui ada tidaknya hubungan antara minat dan motivasi terhadap prestasi belajar mahasiswa Sekolah Tinggi Bahasa Harapan Bersama. Berdasarkan hasil penelitian dapat diambil kesimpulan bahwa ada pengaruh minat belajar dan motivasi belajar terhadap prestasi belajar mahasiswa Sekolah Tinggi Bahasa Harapan Bersama. Dari hasil penelitian tersebut peneliti menyarankan kepada mahasiswa Sekolah Tinggi Bahasa Harapan Bersama agar meningkatkan minat dan motivasi belajar bahasa Mandarin. Selain itu perlu adanya peran serta dari dosen serta adanya peran dari orang tua mahasiswa dalam memotivasi kegiatan belajar yang ditempuh oleh anak mereka.
\end{abstract}

Kata Kunci: minat belajar, motivasi belajar, prestasi belajar

\begin{abstract}
Mastering foreign language are used as a step to improve competence when someone get into the workforce. That awareness lead many Indonesians interested in taking Chinese major for their further study. Interest and motivation are one of the factors which could affect learning achievements. A person with low interest while starting something new will have a sense of laziness and without high learning motivation can make a person lost their interest to continue their activities. Therefore, researchers would like to know if there is an impact of interest and motivation on student achievements at Sekolah Tinggi Bahasa Harapan Bersama. The research method used in this research is descriptive method with data collection techniques through questionnaires and documentary studies where students of Sekolah Tinggi Bahasa Harapan Bersama become the members of population. There are three variables studied in this study, namely: learning interest (X1), learning motivation (X2) and learning achievement (Y). The data analysis technique used is qualitative and quantitative analysis techniques using the SPSS 17.0 program with multiple linear regression to determine whether there is a relationship between
\end{abstract}


interest and motivation towards the learning achievements of Sekolah Tinggi Bahasa Harapan Bersama students. Based on the results, it can be concluded that there is a relationship between learning interest and learning motivation towards the learning achievement of Sekolah Tinggi Bahasa Harapan Bersama students. According to the results of the studies the researchers would like to suggest students of Sekolah Tinggi Bahasa Harapan Bersama to increase their interest and motivation in learning Chinese. Apart from that, researchers also encourage lecturers of Sekolah Tinggi Bahasa Harapan Bersama and parents to motivate childrens on their learning process.

Keywords: learning interest, learning motivation, learning achievement

\section{A. PENDAHULUAN}

Membahas tentang minat tidak lepas dari kejiwaan manusia, apalagi seseorang yang menaruh minat terhadap sesuatu, maka orang tersebut akan berusaha dengan sekuat mungkin untuk memperoleh yang diinginkannya. Upaya-upaya yang dilakukan orang tersebut dapat terjadi karena adanya dorongan lewat minat yang dimilikinya. Dengan demikian, minat adalah motor penggerak yang ada dalam diri seseorang untuk mencapai tujuan yang di cita-citakan.

Menurut Djaali (2008: 121) "Minat adalah rasa lebih suka dan rasa ketertarikan pada suatu hal atau aktivitas, tanpa ada yang menyuruh". Sedangkan menurut Crow \& crow (dalam Djaali, 2008: 121) mengatakan bahwa "minat berhubungan dengan gaya gerak yang mendorong seseorang untuk menghadapi atau berurusan dengan orang, benda, kegiatan, pengalaman yang dirangsang oleh kegiatan itu sendiri". Selain faktor minat dari mahasiswa, faktor penting lainnya adalah motivasi. Hal ini dikarenakan tanpa adanya dorongan atau motivasi dari lingkungan internal maupun eksternal, maka minat belajar yang tadinya tinggi dari seorang mahasiswa lama-kelamaan akan menurun.

Dalam mencapai sebuah tujuan pendidikan, seseorang perlu adanya sebuah dorongan atau motivasi. Motivasi hampir sama pengertiannya dengan motive, drives, dan needs. Menurut Sardiman (2016: 73): "Motivasi berasal dari kata motif yang berarti daya upaya yang mendorong seseorang untuk melakukan sesuatu. Motif dapat juga dapat juga dikatakan sebagai daya penggerak dari dalam dan di dalam subjek untuk melakukan aktivitas-aktivitas tertentu demi mencapai suatu tujuan." Sedangkan menurut Uno (2017: 3): "Motivasi merupakan dorongan yang terdapat dalam diri seseorang untuk berusaha mengadakan perubahan tingkah laku yang lebih baik dalam memenuhi kebutuhannya."

Belajar merupakan sebuah kata yang sudah tidak asing lagi dalam kehidupan. Kata tersebut sudah sering didengar dan diucapkan dalam banyak hal terutama dari orang di rumah tua maupun guru di sekolah. Hal ini terjadi karena proses belajar yang dilakukan oleh manusia tidak akan pernah berhenti sampai kapanpun.

\footnotetext{
${ }^{1}$ Djaali. 2008. Psikologi Pendidikan. Jakarta: Bumi Aksara.

2 Sardiman,A.M., 2016. Interaksi dan Motivasi Belajar-Mengajar. Edisi pertama. Jakarta: Rajawali Pers.

${ }^{3}$ Uno, Hamzah B. 2014. Teori Motivasi dan Pengukurannya. Jakarta: Bumi Aksara.
} 
Belajar merupakan kata kerja yang berasal dari kata ajar atau dengan kata lain ajar merupakan petunjuk yang diberikan kepada orang supaya diketahui atau dituruti. Menurut Slameto (2015: 14): "Belajar adalah proses usaha yang dilakukan seseorang untuk memperoleh suatu pengetahuan tingkah laku yang baru, secara keseluruhan sebagai hasil dari pengalaman sendiri dalam interaksi dengan lingkungannnya."

Sedangkan menurut Uno (2017: 20): “Belajar merupakan perubahan tingkah laku atau penampilan, dengan serangkaian kegiatan misalnya dengan membaca, mengamati, mendengarkan, meniru, dan lain sebagainya." Sehingga dapat disimpulkan bahwa belajar mempunyai arti secara harafiah sebagai upaya sadar untuk menuju pada perubahan yang lebih baik, adapun arti lain dari belajar adalah perubahan yang relatif permanen dalam perilaku atau potensi perilaku sebagai hasil dari pengalaman atau latihan yang diperkuat.

Motivasi belajar dapat dinilai sebagai suatu daya dorong (driving force) yang menyebabkan orang dapat berbuat sesuatu untuk mencapai tujuan, dan tujuan tersebut menyangkut soal prestasi di masa yang akan datang. Prestasi dalam mempelajari bahasa khususnya Bahasa Mandarin dipandang sangat penting mengingat Bahasa Mandarin kini menjadi bahasa internasional yang sudah mendunia dan wajib dipelajari. Selain itu juga tidak dapat dipungkiri bahwa semakin lama semakin banyak lapangan pekerjaan yang membutuhkan karyawan yang mampu Berbahasa Mandarin secara aktif maupun pasif dalam salah satu persyaratan.

Menurut Suryabrata (2002: 23) "menyatakan bahwa prestasi belajar adalah hasil yang dicapai dari hasil latihan, pengalaman yang didukung oleh kesadaran. Jadi prestasi belajar merupakan hasil dari perubahan dalam proses belajar." Sedangkan menurut Arifin (2010:3) "prestasi adalah hasil dari kemampuan, keterampilan, dan sikap seseorang dalam menyelesaikan suatu hal". Berdasarkan pengertian di atas, maka dapat disimpulkan bahwa prestasi belajar merupakan tingkat keberhasilan dalam proses pembelajaran setelah melalui tahap tes yang dinyatakan dalam bentuk nilai berupa angka. Prestasi belajar dapat diketahui setelah melakukan evaluasi dan evaluasi dapat memperlihatkan tentang tinggi atau rendahnya prestasi belajar.

Di dalam jurnal ini dibahas peran minat dan motivasi belajar terhadap prestasi mahasiswa. Uji instrumen dalam penelitian ini menggunakan uji validitas dan uji reliabilitas. Sedangkan analisis data menggunakan analisis regresi linear berganda agar diperoleh hasil yang akurat.

\footnotetext{
${ }^{4}$ Slameto. 2015. Belajar dan Faktor-faktor yang Mempengaruhinya. Jakarta: PT Rineka Cipta.

${ }^{5}$ Uno, Hamzah B. 2014. Teori Motivasi dan Pengukurannya. Jakarta: Bumi Aksara.

${ }^{6}$ Suryabrata, Sumadi. 2002. Psikologi Pendidikan. Banjarmasin: Rajawali Pers.

${ }^{7}$ Arifin, Zainal., 2010. Evaluasi Pembelajaran. Bandung: Rosda.
} 
Menurut Surya (2003:100): “Minat dapat diartikan sebagai rasa senang atau tidak senang dalam menghadapi suatu objek.

Crow dan Crow (1973: 22) menerangkan bahwa faktor-faktor yang mempengaruhi minat seseorang ada tiga, yaitu:

a) The factor inner urge (faktor dorongan dari dalam) Rangsangan yang datang dari lingkungan atau ruang lingkup yang sesuai dengan keinginan atau kebutuhan seseorang akan mudah menimbulkan minat. Dalam hal ini minat seseorang akan tumbuh bila ada dorongan dalam dirinya sendiri, bukan dorongan dari orang lain.

b) The factor of social motivate (motif sosial) Motif sosial dapat menjadi faktor yang membangkitkan minat untuk melakukan aktivitas tertentu karena ingin mendapatkan perhatian, penghargaan dari orang lain dan masyarakat.

c) Emosional factor (faktor emosional) Minat sangat berhubungan dengan emosi. Jika seseorang mendapatkan kesuksesan pada aktivitas akan menimbulkan perasaan senang, dan hal tersebut akan memperkuat akan memperkuat minatnya terhadap aktivitas tersebut, sebaliknya suatu kegagalan akan menghilangkan minatnya terhadap hal tersebut.

Menurut McDonald, motivasi adalah perubahan energi dalam diri seseorang yang ditandai dengan munculnya rasa/feeling dan didahului dengan tanggapan terhadap adanya tujuan. Ada tiga elemen penting dalam motivasi:

a) Bahwa motivasi mengawali terjadinya perubahan energi pada diri setiap individu manusia.

b) Motivasi ditandai dengan munculnya rasa/feeling afeksi seseorang.

c) Motivasi akan dirangsang karena adanya tujuan

Menurut Uno (2017: 23) ada enam indikator motivasi dalam belajar yaitu:

a) Adanya hasrat dan keinginan berhasil

b) Adanya dorongan dan kebutuhan dalam belajar

c) Adanya harapan dan cita-cita masa depan

d) Adanya penghargaan dalam belajar

e) Adanya kegiatan yang menarik dalam belajar

f) Adanya lingkungan belajar yang kondusif

\footnotetext{
${ }^{8}$ Surya, Mohamad. 2003. Strategi Kognitif dalam Proses Pembelajaran. Bandung: Alfabeta.

${ }^{9}$ Uno, Hamzah B. 2014. Teori Motivasi dan Pengukurannya. Jakarta: Bumi Aksara.
} 
Menurut Riduwan (2003: 174): Hipotesis teoritis adalah proposisi yang menetapkan hubungan antara variabel. Hipotesis ini diperoleh melalui operasionalisasi yaitu proses mengubah istilah-istilah abstrak (konsep-konsep) menjadi istilah-istilah empiris (variabel-variabel). Hipotesis teoritis merupakan proposisi yang paling rendah di dalam struktur teori dan merupakan hubungan antara proposisi tingkat tinggi dengan observasi. Hipotesis ini memungkinkan diadakannya pengujian teori. Berdasarkan uraian teori diatas dapat diuraikan hipotesis sebagai berikut: Terdapat pengaruh yang signifikan antara minat dan motivasi terhadap prestasi belajar mahasiswa pada Sekolah Tinggi Bahasa Harapan Bersama Pontianak.

\section{B. METODE PENELITIAN}

Dalam penelitian ini penulis menggunakan metode deskriptif, dimana penulis menggambarkan keadaan sebenarnya berdasarkan fakta yang ada pada Sekolah Tinggi Harapan Bersama di Pontianak. Menurut Nasution (2004: 24): "Penelitian deskriptif adalah mengadakan deskripsi untuk memberi gambaran yang lebih jelas tentang situasi-situasi sosial seperti kehidupan mahasiswa di rumah kontakan, perusahaan transpor lokal di suatu kota, sistem penerimaan pegawai baru pada perusahaan baru dan sebagainya."

\subsection{Teknik Pengumpulan Data}

a. Observasi

Yaitu dengan cara mengumpulkan data dengan melakukan pengamatan secara langsung terhadap masing-masing objek penelitian, dalam hal ini adalah Sekolah Tinggi Bahasa Harapan Bersama Pontianak. Menurut Hadi (2004: 151): "Observasi biasa diartikan sebagai pengamatan dan pencatatan dengan sistematis atas fenomena-fenomena yang diteliti."

b. Wawancara

Yaitu pengumpulan data dengan melakukan tanya jawab secara langsung dengan mahasiswa Sekolah Tinggi Bahasa Harapan Bersama Pontianak serta responden yang berhubungan dengan penelitian ini.

\footnotetext{
${ }^{10}$ Riduwan. 2003. Dasar-dasar Statistika. Bandung:Alfabeta.

${ }^{11}$ S. Nasution. 2004. Metode Research (judul asli:Penelitian Ilmiah), edisi pertama. Jakarta: PT Bumi Aksara.
} 
c. Kuesioner

Menurut Nasution (2004: 128): "Kuesioner adalah daftar pertanyaan yang didistribusikan melalui pos untuk diisi dan dikembalikan atau dapat juga dijawab dibawah pengawasan peneliti." Dalam metode ini, penulis menyebarkan kuesioner kepada para mahasiswa yang sedang menjalankan proses perkuliahan di Sekolah Tinggi Harapan Bersama Pontianak untuk memperoleh data yang relevan dengan tujuan penelitian.

d. Studi Dokumenter

Yaitu teknik pengumpulan data-data yang diperoleh dari sumber-sumber seperti literatur buku-buku, serta dokumen lainnya yang berhubungan dengan masalah yang diteliti.

\subsection{Populasi dan Sampel}

a. Populasi

Menurut Fathoni (2006: 103): “Populasi ialah keseluruhan unit elementer yang parameternya akan diduga melalui statistika hasil analisis yang dilakukan terhadap sampel penelitian." Adapun yang menjadi populasinya adalah seluruh mahasiswa yang menjalankan proses perkuliahan di Sekolah Tinggi Harapan Bersama dari tahun 2016 sampai dengan tahun 2018.

b. Sampel

Sampel merupakan bagian atau sejumlah cuplikan tertentu yang diambil dari suatu populasi yang dipergunakan untuk memperkirakan karakteristik populasi dan diteliti secara rinci. Informasi yang diperoleh kemudian diterapkan pada keseluruhan populasi.

Menurut Jogiyanto (2008: 69): "Sampel yang baik merupakan sample yang akurat dan tepat."

Menurut Gay yang dikutip oleh Umar (2004: 79): “Ukuran minimum sampel yang dapat diterima apabila penelitian menggunakan metode deskriptif-korelasional adalah minimal 30 subjek." Dalam penulisan ini, penulis menetapkan sampel sebanyak 100 responden. Metode pengambilan sampel dalam penelitian ini menggunakan metode Purposive Sampling, yaitu teknik sampling yang digunakan peneliti jika peneliti mempunyai pertimbangan tertentu di dalam pengambilan sampelnya atau penentuan sampel untuk tujuan tertentu, dengan ciri-ciri responden adalah mahasiswa yang sedang menjalankan proses perkuliahan di Sekolah Tinggi Harapan Bersama Pontianak selama tiga tahun terakhir, yaitu tahun 2016 sampai dengan tahun 2018.

\footnotetext{
${ }^{13}$ S. Nasution. 2004. Metode Research (judul asli:Penelitian Ilmiah), edisi pertama. Jakarta: PT Bumi Aksara.

${ }^{14}$ Fathoni, Abdurrahmat. 2006. Metodologi Penelitian dan Teknik Penyusunan Skripsi. Jakarta: PT Rineka Cipta.

${ }^{15}$ Hartono, Jogiyanto. 2006. Metode Penelitian Sistem Informasi, edisi pertama. Yogyakarta:Andi.

${ }^{16}$ Umar, Husein. 2008. Metode Penelitian Untuk Skripsi dan Tesis Bisnis. Edisi dua. Jakarta: Raja Grafindo Persada.
} 
Dalam melakukan penelitian ini, penulis telah mengumpulkan dan menyebarkan 100 kuesioner kepada responden dan semua kuesioner yang disebarkan tersebut telah dikembalikan kepada peneliti atau dengan kata lain penelitian ini mempunyai response rate sebesar 100 persen. Dari hasil pengumpulan kuisioner, diketahui bahwa total responden yang berjenis kelamin pria berjumlah 15 orang atau response rate mahasiswa berjenis kelamin pria sebesar 15 persen dan total responden yang berjenis kelamin wanita berjumlah 85 orang atau response rate mahasiswa berjenis kelamin wanita sebesar 85 persen.

\subsection{Teknik Analisis Data}

a. Alat Analisis Kualitatif

Untuk menganalisis data yang diperoleh dari hasil penelitian, digunakan alat analisis kualitatif. Di mana jawaban responden dari kuesioner yang disebar, kemudian dikelompokkan berdasarkan kriteria yang ditetapkan dan hasil dari masing-masing jawaban dijumlahkan, dihitung menggunakan Skala Likert, selanjutnya dianalisis untuk mendapatkan hasil dan kesimpulan.

Menurut Durianto, Sugiarto, dan Sitinjak (2001: 70): "dalam penggunaan skala Likert ini peneliti menggunakan skala lima tingkat yang masing-masing penilaian atau jawaban tersebut diberi bobot sebagai berikut:

$\begin{array}{ll}\text { Skala Likert } & \text { Rentang } \\ \text { Sangat Setuju } & \text { : bobot } 5 \\ \text { Setuju } & \text { : bobot } 4 \\ \text { Kurang Setuju } & \text { : bobot } 3 \\ \text { Tidak Setuju } & \text { : bobot } 2 \\ \text { Sangat Tidak Setuju } & \text { : bobot } 1\end{array}$

Untuk mengetahui kriteria minat dan motivasi maka dapat menggunakan rumus statistik rentang nilai:

$$
\begin{aligned}
& \text { Rentang }=\frac{\mathrm{n}-1}{\mathrm{n}} \\
& \text { Di mana: }
\end{aligned}
$$

$\mathrm{n}=$ jumlah bobot penilaian

Pada penelitian ini jumlah bobot dalam penilaian adalah lima nilai. Rentang penilaian dalam penelitian ini adalah sebagai berikut:

Rentang $=\frac{5-1}{5}=\frac{4}{5}=0,80$

\footnotetext{
17 Umar, Husein. 2008. Metode Penelitian Untuk Skripsi dan Tesis Bisnis. Edisi dua. Jakarta: Raja Grafindo Persada.

${ }^{18}$ Durianto, Darmadi, Sugiarto, dan Tony Sitinjak. 2001 Strategi Menaklukkan Pasar Melalui Riset Ekuitas dan Perilaku Merek. Jakarta: PT Gramedia Pustaka Utama.
} 
Dengan rentang $=0,80$ bobot, maka diperoleh rentang penilaian sebagai berikut:

TABEL 1: TABEL INTERPRETASI SKALA LIKERT

[Sumber: Data Olahan SPSS 17.0]

\begin{tabular}{|l|c|}
\hline \multicolumn{1}{|c|}{ Tingkat Hubungan } & Interval \\
\hline Sangat Setuju (SS) & $4,20-5,00$ \\
\hline Setuju (S) & $3,40-4,19$ \\
\hline Kurang Setuju (KS) & $2,60-3,39$ \\
\hline Tidak Setuju (TS) & $1,80-2,59$ \\
\hline Sangat Tidak Setuju (STS) & $1,00-1,79$ \\
\hline
\end{tabular}

b. Alat Analisis Kuantitatif

Dalam analisis kuantitatif ini akan dilakukan analisis dengan metode regresi linear berganda (multipel) untuk mengetahui kuatnya pengaruh dari seluruh variabel independen $(X)$ terhadap variabel dependen $(Y)$ pada permasalahan ke 3 yaitu pengaruh dari masing-masing variabel minat dan motivasi terhadap prestasi belajar. Bentuk umum persamaan regresi linear berganda dapat ditulis sebagai berikut :

$$
Y=a+b 1 X 1+b 2 X 2+b 3 X 3
$$

Keterangan:

$\mathrm{Y}=$ Prestasi Akademik

$\mathrm{a}=$ Konstanta

$\mathrm{b}=$ Koefisien regresi yang menunjukkan angka peningkatan atau penurunan variabel dependen yang didasarkan pada variabel independen.

$\mathrm{X} 1$ = The Factor Inner Urge (faktor dorongan dari dalam)

$\mathrm{X} 2=$ The Factor of Social Motivate (motif sosial)

X3 = Emotional Factor (faktor emosional)

Nilai dari koefisien a, b1, b2 dan selanjutnya dapat ditentukan dengan persamaan:

$\Sigma Y=a \cdot n+b 1 \Sigma X 1+b 2 \Sigma X 2$

$\Sigma X 1 Y=a . \Sigma X 1+b 1 \Sigma X 1^{2}+b 2 \Sigma X 1 \Sigma X 2$

$\Sigma X 2 Y=a \cdot \Sigma X 2+b 1 \Sigma X 1 X 2+b 2 \Sigma X 2^{2}$

\section{HASIL DAN PEMBAHASAN}

\subsection{Uji Signifikasi Dengan Tabel Anova $\left(F_{\text {hitung }}\right)$ Secara Keseluruhan}

Pengaruh Variabel Minat dan Motivasi Terhadap Prestasi akan diuji dalam analisa

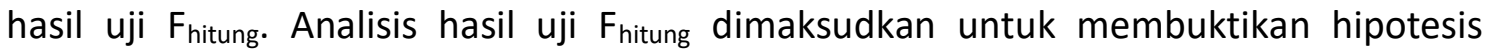
pertama yang diajukan dalam penelitian ini yaitu bahwa variabel minat dan motivasi mempunyai pengaruh signifikan terhadap prestasi. Dengan uji signifikasi $F$, didapatkan $F_{\text {hitung }}$ yang dapat dilihat pada Tabel Anova berikut ini: 
TABEL 2: HASIL ANALISIS UJI F PENGARUH VARIABEL INDEPENDEN (Xi)

TERHADAP VARIABEL DEPENDEN (Y)

SUMBER: [Data Olahan SPSS 17.0]

ANOVA $^{\text {b }}$

\begin{tabular}{|ll|r|r|r|r|r|}
\hline \multicolumn{1}{|l|}{} & Sum of Squares & Df & Mean Square & F & Sig. \\
\hline 1 & Regression & 6.940 & 3 & 2.313 & 19.655 & $.000^{\mathrm{a}}$ \\
& Residual & 11.300 & 96 & .118 & & \\
& Total & 18.240 & 99 & & & \\
\hline
\end{tabular}

a. Predictors: (Constant), Emotional_Factor, The_Factor_of_Social_Motivate, The_Factor_Inner_Urge

b. Dependent Variable: Prestasi Belajar

Berdasarkan Tabel diatas, maka hipotesis dapat dirumuskan sebagai berikut :

Ho: Tidak ada hubungan secara signifikan antara variabel bebas the factor inner urge (faktor dorongan dari dalam), the factor of social motivate (motif sosial), dan emotional factor (faktor emosional) terhadap variabel terikat prestasi belajar.

Ha: Ada hubungan secara signifikan antara variabel bebas the factor inner urge (faktor dorongan dari dalam), the factor of social motivate (motif sosial), dan emotional factor (faktor emosional) terhadap variabel terikat prestasi belajar.

Kriteria uji hipotesis:

1) Jika $F_{\text {hitung }}>F_{\text {tabel }}$ maka Ho ditolak dan Ha diterima

2) Jika $F_{\text {hitung }} \leq F_{\text {tabel }}$ maka Ho diterima dan Ha ditolak

Dari Tabel diatas dapat diketahui bahwa $F_{\text {hitung }}$ yang didapat adalah sebesar 19,655 dan dengan menggunakan tingkat atau taraf kesalahan sebesar lima persen $(\alpha=0,05)$, maka didapatkan $F_{\text {tabel }}$ sebesar 2,467. Dengan demikian, nilai $F_{\text {hitung }}$ lebih besar dari $F_{\text {tabel. }}$ Hal ini berarti variabel bebas the factor inner urge (faktor dorongan dari dalam) $\mathrm{X}_{1}$, the factor of social motivate (motif sosial) $\mathrm{X}_{2}$, dan emotional factor (faktor emosional) $X_{3}$ secara keseluruhan memiliki pengaruh yang signifikasi terhadap variabel terikat prestasi belajar $(\mathrm{Y})$.

\subsection{Uji t secara parsial untuk mengukur signifikasi koefisien regresi pada persamaan regresi linear berganda}

Uji t digunakan untuk menguji signifikansi hubungan antara variabel $X$ dan $Y$, apakah variabel $\mathrm{X}_{1}, \mathrm{X}_{2}$, dan $\mathrm{X}_{3}$ (the factor inner urge, the factor of social motivate dan emotional factor) benar-benar berpengaruh terhadap variabel $Y$ (prestasi belajar). Pengaruh variabel minat dan motivasi terhadap prestasi akan diuji dalam hasil analisis uji $t_{\text {hitung }}$ yang digunakan untuk membuktikan hipotesis kedua yang menyatakan bahwa variabel minat dan motivasi tidak mempunyai pengaruh signifikan terhadap prestasi belajar. Hasil uji $t_{\text {hitung }}$ dapat dilihat pada Tabel berikut ini: 
TABEL 3: HASIL ANALISA UI T PENGARUH VARIABEL INDEPENDEN (Xi) TERHADAP VARIABEL DEPENDEN (Y)

SUMBER: [Data Olahan SPSS 17.0]

\begin{tabular}{|c|c|c|c|c|c|c|}
\hline \multicolumn{7}{|c|}{ Coefficients $^{\mathrm{a}}$} \\
\hline \multirow{2}{*}{\multicolumn{2}{|c|}{ Model }} & \multicolumn{2}{|c|}{$\begin{array}{c}\text { Unstandardized } \\
\text { Coefficients }\end{array}$} & \multirow{2}{*}{$\begin{array}{c}\begin{array}{c}\text { Standardized } \\
\text { Coefficients }\end{array} \\
\text { Beta }\end{array}$} & \multirow[b]{2}{*}{$\mathrm{t}$} & \multirow[b]{2}{*}{ Sig. } \\
\hline & & B & Std. Error & & & \\
\hline \multirow[t]{4}{*}{1} & (Constant) & 1.837 & .329 & & 5.576 & .000 \\
\hline & The Factor Inner Urge & .422 & .091 & .464 & 4.622 & .000 \\
\hline & The Factor of Social Motivate & .136 & .058 & .219 & 2.331 & .022 \\
\hline & Emotional Factor & .290 & .083 & .360 & 3.460 & .037 \\
\hline
\end{tabular}

a. Dependent Variable: Prestasi belajar

1. Pengujian terhadap variabel the factor inner urge (faktor dorongan dari dalam)

Kriteria hipotesis:

Ho : Tidak ada pengaruh yang signifikan antara the factor inner urge (faktor dorongan dari dalam) terhadap prestasi belajar.

$\mathrm{Ha}$ : Ada pengaruh yang signifikan antara the factor inner urge (faktor dorongan dari dalam) terhadap prestasi belajar.

Nilai $t_{\text {hitung }}$ yang diperoleh adalah sebesar 4,622 dan $t_{\text {tabel }}$ sebesar 1,661 sehingga $t_{\text {hitung }}$ lebih besar dari $t_{\text {tabel }}(4,622>1,661)$ dan sig. $t_{\text {hitung }}$ sebesar 0,000 lebih kecil dari $0,05(0,000<0,05)$ maka Ho ditolak dan Ha diterima. Hal ini berarti bahwa the factor inner urge (faktor dorongan dari dalam) seperti belajar Bahasa Mandarin merupakan hal yang menarik bagi mahasiswa, mengikuti kegiatan belajar Bahasa Mandarin dengan senang hati, mahasiswa membuat jadwal belajar praktek Bahasa Mandarin bersama teman-teman untuk memudahkan kegiatan belajar di kelas, mahasiswa aktif dalam kesempatan bertanya, dan mahasiswa mempelajari kembali materi yang diajarkan di rumah setelah proses perkuliahan selesai secara parsial mempunyai pengaruh yang signifikan terhadap prestasi belajar.

2. Pengujian terhadap variabel the factor of social motivate (motif sosial) Kriteria hipotesis:

Ho: Tidak ada pengaruh yang signifikan antara the factor of social motivate (motif sosial) terhadap prestasi belajar.

$\mathrm{Ha}$ : Ada pengaruh yang signifikan antara the factor of social motivate (motif sosial) terhadap prestasi belajar.

Nilai $t_{\text {hitung }}$ yang diperoleh adalah sebesar 2,331 dan $t_{\text {tabel }}$ sebesar 1,661 sehingga $t_{\text {hitung }}$ lebih besar dari $t_{\text {tabel }}(2,331>1,661)$ dan sig. $t_{\text {hitung }}$ sebesar 0,022 lebih kecil dari 0,05 $(0,022<0,05)$ maka Ho ditolak dan Ha diterima. Hal ini berarti bahwa the factor of social motivate (motif sosial) seperti adanya 
pemberian pujian dari dosen bila mahasiswa mendapatkan nilai yang baik dalam ujian, dosen selalu menunjukkan hasil ujian kepada mahasiswa sebagai pemacu motivasi untuk mendapat nilai yang lebih baik lagi, setiap kali ujian dosen selalu menjanjikan hadiah apabila mahasiswa mendapat nilai yang terbaik, sesama mahasiswa akan kagum dengan prestasi yang mahasiswa terbaik capai saat ini sehingga memacu prestasi saat ini, dan orang tua mahasiswa selalu memberikan pujian dan dorongan yang membuat mahasiswa selalu bersemangat dalam menjalankan perkuliahan secara parsial mempunyai pengaruh yang signifikan terhadap prestasi belajar.

3. Pengujian terhadap variabel emotional factor (faktor emosional)

Kriteria hipotesis :

Ho: Tidak ada pengaruh yang signifikan antara emotional factor (faktor emosional) terhadap prestasi belajar.

$\mathrm{Ha}$ : Ada pengaruh yang signifikan antara emotional factor (faktor emosional) terhadap prestasi belajar.

Nilai $t_{\text {hitung }}$ yang diperoleh adalah sebesar 3,460 dan $t_{\text {tabel }}$ sebesar 1,661 sehingga $t_{\text {hitung }}$ lebih besar dari $t_{\text {tabel }}(3,460>1,661)$ dan sig. $t_{\text {hitung }}$ sebesar 0,037 lebih kecil dari $0,05(0,037<0,05)$ maka Ho diterima dan Ha ditolak. Hal ini berarti bahwa variabel emotional factor (faktor emosional) seperti membuat mahasiswa tetap akan bersemangat dalam belajar ketika mendapat nilai yang jelek, membuat mahasiswa menyesuaikan diri untuk tetap belajar walaupun mata kuliah yang diajar oleh dosen yang kurang mahasiswa sukai, membuat mahasiswa untuk tetap meminta izin mengikuti proses perkuliahan meskipun terlambat masuk kelas dan ditegur dosen dibandingkan untuk bolos, walapun memiliki kegiatan lain mahasiswa tetap akan meluangkan waktu untuk belajar Bahasa Mandarin karena belajar Bahasa Mandarin merupakan kesenangan mahasiswa, dan membuat mahasiswa bersemangat ketika mendapat tugas yang belum pernah mereka pahami sebelumnya secara parsial mempunyai pengaruh yang signifikan terhadap prestasi belajar.

\section{KESIMPULAN}

Berdasarkan hasil analisis statistik untuk the factor inner urge (faktor dorongan dari dalam) $X_{1}$, the factor of social motivate (motif sosial) $X_{2}$, emotional factor (faktor emosional) $X_{3}$, dan prestasi belajar mahasiswa (Y) pada Sekolah Tinggi Harapan Bersama Pontianak, didapat bahwa:

a. Secara simultan maupun parsial terdapat pengaruh signifikan antara ketiga variabel independen yaitu the factor inner urge (faktor dorongan dari dalam), the factor of social motivate (motif sosial), dan emotional factor (faktor emosional) terhadap prestasi akademik mahasiswa pada Sekolah Tinggi Harapan Bersama Pontianak.

b. Nilai koefisien the factor inner urge (faktor dorongan dari dalam) $\mathrm{X}_{1}$, the factor of social motivate (motif sosial) $\mathrm{X}_{2}$, emotional factor (faktor emosional) $\mathrm{X}_{3}$ masingmasing adalah 4,622, 2,331, dan 3,460 sehingga memiliki pengaruh yang cukup baik terhadap prestasi akademik mahasiswa pada Sekolah Tinggi Harapan Bersama Pontianak. Demikian pula dengan nilai signifikansi $F$ yang bernilai 19,655 
mengakibatkan persamaan regresi yang dihasilkan signifikan sehingga the factor inner urge (faktor dorongan dari dalam), the factor of social motivate (motif sosial), dan emotional factor (faktor emosional) dapat digunakan untuk penilaian prestasi akademik mahasiswa.

\section{E. SARAN-SARAN}

a. Sebaiknya Sekolah Tinggi Bahasa Harapan Bersama Pontianak tetap mempertahankan minat dan motivasi belajar mahasiswa. Hal ini dapat terlihat dari hasil analisa yang menunjukkan bahwa dengan adanya minat dan motivasi yang tinggi dalam belajar akan meningkatkan prestasi akademik mahasiswa. Di samping itu, Sekolah Tinggi Bahasa Harapan Bersama juga harus mempertahankan faktor-faktor yang menjadi minat dan motivasi mahasiswa dalam akademik mereka seperti hasrat dan keinginan untuk berhasil, dorongan dan kebutuhan dalam belajar, harapan dan cita-cita masa depan, adanya penghargaan dalam belajar, kegiatan yang menarik dalam belajar, serta menciptakan lingkungan belajar yang kondusif.

b. Selain itu Sekolah Tinggi Bahasa Harapan Bersama juga harus mempertahankan faktor-faktor pembentuk minat dan motivasi mahasiswa dalam prestasi akademik mahasiswa seperti the factor inner urge (faktor dorongan dari dalam) diantaranya seperti belajar Bahasa Mandarin merupakan hal yang menarik bagi mahasiswa, mengikuti kegiatan belajar Bahasa Mandarin dengan senang hati, mahasiswa membuat jadwal belajar praktek Bahasa Mandarin bersama temanteman untuk memudahkan kegiatan belajar di kelas, mahasiswa aktif dalam kesempatan bertanya, dan mahasiswa mempelajari kembali materi yang diajarkan di rumah setelah proses perkuliahan selesai.

c. Sekolah Tinggi Bahasa Harapan Bersama juga harus mempertahankan faktorfaktor pembentuk minat dan motivasi mahasiswa dalam prestasi akademik mahasiswa seperti the factor of social motivate (motif sosial) diantaranya seperti adanya pemberian pujian dari dosen bila mahasiswa mendapatkan nilai yang baik dalam ujian, dosen selalu menunjukkan hasil ujian kepada mahasiswa sebagai pemacu motivasi untuk mendapat nilai yang lebih baik lagi, setiap kali ujian dosen selalu menjanjikan hadiah apabila mahasiswa mendapat nilai yang terbaik, sesama mahasiswa akan kagum dengan prestasi yang mahasiswa terbaik capai saat ini sehingga memacu prestasi saat ini, dan orang tua mahasiswa selalu memberikan pujian dan dorongan yang membuat mahasiswa selalu bersemangat dalam menjalankan perkuliahan.

d. Sekolah Tinggi Bahasa Harapan Bersama juga harus mempertahankan faktorfaktor pembentuk minat dan motivasi mahasiswa dalam prestasi akademik mahasiswa seperti emotional factor (faktor emosional) diantaranya seperti membuat mahasiswa tetap akan bersemangat dalam belajar ketika mendapat nilai yang jelek, membuat mahasiswa menyesuaikan diri untuk tetap belajar walaupun mata kuliah yang diajar oleh dosen yang kurang mahasiswa sukai, membuat mahasiswa untuk tetap meminta izin mengikuti proses perkuliahan meskipun terlambat masuk kelas dan ditegur dosen dibandingkan untuk bolos, walapun memiliki kegiatan lain mahasiswa tetap akan meluangkan waktu untuk 
belajar Bahasa Mandarin karena belajar Bahasa Mandarin merupakan kesenangan mahasiswa, dan membuat mahasiswa bersemangat ketika mendapat tugas yang belum pernah mereka pahami sebelumnya.

\section{DAFTAR PUSTAKA}

[1] Arifin, Zainal., 2010. Evaluasi Pembelajaran. Bandung: Rosda.

[2] Djaali. 2008. Psikologi Pendidikan. Jakarta: Bumi Aksara.

[3] Durianto, Darmadi, Sugiarto, dan Tony Sitinjak. 2001 Strategi Menaklukkan Pasar Melalui Riset Ekuitas dan Perilaku Merek. Jakarta: PT Gramedia Pustaka Utama.

[4] Fathoni, Abdurrahmat. 2006. Metodologi Penelitian dan Teknik Penyusunan Skripsi. Jakarta: PT Rineka Cipta.

[5] Hartono, Jogiyanto. 2006. Metode Penelitian Sistem Informasi, edisi pertama. Yogyakarta:Andi.

[6] Hadi, Sutrisno. 2004. Metodologi Riset, edisi ketiga. Yogyakarta:Andi.

[7] Nasution S. 2004. Metode Research (judul asli:Penelitian IImiah), edisi pertama. Jakarta: PT Bumi Aksara.

[8] Riduwan. 2003. Dasar-dasar Statistika. Bandung:Alfabeta.

[9] Sardiman,A.M., 2016. Interaksi dan Motivasi Belajar-Mengajar. Edisi pertama. Jakarta: Rajawali Pers.

[10] Slameto. 2015. Belajar dan Faktor-faktor yang Mempengaruhinya. Jakarta: PT Rineka Cipta.

[11] Surya, Mohamad. 2003. Strategi Kognitif dalam Proses Pembelajaran. Bandung: Alfabeta.

[12] Suryabrata, Sumadi. 2002. Psikologi Pendidikan. Banjarmasin: Rajawali Pers.

[13] Umar, Husein. 2008. Metode Penelitian Untuk Skripsi dan Tesis Bisnis. Edisi dua. Jakarta: Raja Grafindo Persada.

[14] Uno, Hamzah B. 2014. Teori Motivasi dan Pengukurannya. Jakarta: Bumi Aksara.

\section{DATA PENULIS}

Nama

Program studi

Perguruan Tinggi

Telp.

Email
: Wiliyanti Then, S.E., MTCSOL.

: S1 Bahasa Mandarin

: Sekolah Tinggi Bahasa Harapan Bersama, Pontianak

: +6287819035629

: wiliyanti@stbharapanbersama.ac.id 